\title{
Financial Market Regulation and the Dynamics of Inclusion and Exclusion
}

\author{
Peter Mooslechner, Helene Schuberth and \\ Beat Weber $^{1}$
}

\section{GLOBALIZATION AND FINANCIAL GOVERNANCE}

Financial systems and the prevailing monetary landscape are the outcome of a cognizant political choice among a set of alternative options rather than the inevitable result of the force of economic logic that sorts out the most efficient from the less proficient arrangements in a Darwinian struggle (Kirshner 2003, p. 655). However, the latter narrative is fairly powerful. It creates the illusion that policy has no choice but to react in favor of the claims of financial capital, while controlling it is considered neither technically feasible nor desirable. This view is reasonably consistent with a recent wave of re-regulatory efforts to strengthen the stability of the financial sector. Regulatory arrangements such as Basel II or those in line with the Washington Consensus principles are - among many other available choices - the liberal response to financial crisis and to signs of unsustainability in the financial system (see Redak in this volume). In many cases, the reaction is not deregulation, but marketoriented re-regulation. The view that financial regulation inevitably converges toward a pro-market regulation model owes its vigor to the threat of exit of financial capital in globalized economies. Market-driven (re-)regulation is further supported by efficiency-related arguments. However, as pointed out by Grabel (2003), it might well be the case that the efficiency and legitimacy of policies forced by the vote of financial markets are deceptive in nature; they are more the result of a pathdependent self-fulfilling prophecy than the revelation of optimality.

However, if policy options are manifold and feasible (albeit in some ways restricted) in light of market logic, questions arise as to what

\footnotetext{
${ }^{1}$ The views expressed in this book are those of the authors and do not necessarily represent those of their employer.
} 
mechanisms explain the prevailing policy choices taken. Can the claim that 'money is politics' (Kirshner 2003, p. 645) be maintained, that political forces are the dominant factor in shaping regulation given worldwide convergence toward a liberal mode of financial governance? An influential approach explaining the driving factors behind the recent wave of reform attempts in financial governance mechanisms stresses the role of non-state and private actors in emerging transnational policy processes and the migration of political authority to supranational levels, which increasingly share elements of authority with their member states in regulatory reform. Competing and overlapping structures have emerged, with formal and informal interrelationships between public and private bodies, networks and webs which appear to be as complex as and similar to medieval times (Cerny 2005). Thus the inherently multi-level nature of finance precipitates multi-level institutional processes and practices. This has been associated with a change in the logic of democratic accountability in democracies which are restricted to the nation-state level. In key areas of policymaking, multi-level governance by supranational, private, technical and popular sources of authority has undermined traditional nation-state based mechanisms of democratic accountability (such as elections and legislation), while in procedural terms the public sector still plays a key role in setting standards (Porter 2001 and in this volume). In global finance, the state has gone particularly far in willingly accepting the shift of regulatory competences to private institutions, as indicated by the evolving mechanisms of selfregulation and co-regulation in financial governance (for example in the form of codes of conduct).

\section{POLITICAL ECONOMY OF FINANCIAL REFORM}

Theoretical explanations of the recent financial governance trends described above are manifold but can mainly be condensed into two broad lines of research: economic theories and political economy theories of regulatory reform.

One influential strand of literature among the economic theories of the political economy of financial governance focuses on efficiency-related explanations of reforms in financial governance (for a critique, see Underhill in this volume). In these approaches, as a rational decision maker the state aims for optimal governance which safeguards financial stability and provides underpinnings for the successful operation of markets. The high degree of involvement of experts and 'committees of wise men' in regulation would safeguard the scientific, non-interestbased optimal resolution of policy dilemmas concerning alternative forms of regulation in different market settings. But regulatory modes change 
with time and political proclivity. The International Monetary Fund, to give a prominent example, favors the sequential and cautious liberalization of capital accounts today, while ten years ago it considered instantaneous and full liberalization to be the essential ingredient in successful development strategies for transition and emerging economies. What is considered optimal is bound to change repeatedly. Furthermore, in the recent past, financial crises have occurred too often to regard efficiency-related explanations of regulatory reform as truly convincing and viable.

In his investigation of regulatory responses to financial crises in the United States in the $20^{\text {th }}$ century, Jonathan Macey (1998) argues that the reform measures taken did not so much reduce the financial sector's exposure to risk, but benefited those specific interest groups and constituencies which lobbied more effectively than others. Hence, the economic theories of the political economy of financial reform have been particularly challenged by political economy theories of regulatory reform which view governance as an outcome of conflicting interests. They devote special attention to the state-market relationship. Rather than being separate or even opposed units (as is usually assumed in the literature), in many cases states are observed to form alliances with private actors in financial liberalization (see Lütz in this volume) and to drive globalization toward neoliberal outcomes. As argued by Cerny (2005), this is not accompanied by a retreat of the state but by the role of the state as an enforcer of rules which is perceived to follow the trends of financial globalization. But why has the state become a facilitator of global processes rather than a protector of national incumbents? Is it because the state is simply overburdened in controlling the forces set free by liberalization, as it is faced with conflicting pressures and the ad hoc tactics of many actors? Or can it be explained as a consequence of a conscious strategy bringing about the transformation of an interventionist into a competitive and/or regulatory state that requires regulatory standards which favor dominant market participants? While it is easier to identify the private sector's interests in terms of economic benefits due to specific regulations, state interests are difficult to scrutinize and impossible to generalize across regulatory fields and regions. One major drawback of the political economy theories of financial governance is that they limit their analysis to describing regulation as an outcome of various actors forming coalitions against others, without further deconstructing the substance of interests followed by those actors. With this focus on procedure rather than substance, crucial questions remain unanswered: Are the actors' interests purely economic or also political, social and cultural? Do governance outcomes stem from the unintended consequences of actors' decisions (Streeck 2003) taken under fundamental uncertainty about economic, political and distributional 
effects? Is there a causal influence of ideas and discourse in the formulation of policies? By which instruments - formal (procedure) and informal (values) - is authority exercised?

\section{INCLUSION AND EXCLUSION IN FINANCIAL GOVERNANCE}

The contributions in this volume do not investigate all of these issues, but they share a common perspective of analyzing the political economy of regulatory change. This allows us to address the entire spectrum of questions raised above. The authors examine governance arrangements in the financial sphere as the outcome of political economy conflicts which are linked to inclusive and exclusive processes.

Financial governance is understood as the definition, application and enforcement of the rules of the game (Kjaer 2004) in financial systems. This comprises formal and informal rules and can be enacted by private as well as public actors. The process of designing financial governance is contested terrain. The resulting institutional setup involves inclusion and exclusion. In the existing literature, exclusion refers to individuals who are prevented from participating in certain activities of society. Two aspects seem relevant for our purposes: In the economic area, exclusion refers to an inability (or at least a severely limited ability) to participate in the overall welfare of society. In the political area, for instance in financial regulation, exclusion refers to affected groups that are not permitted to contribute effectively to financial market regulation, which has important consequences for the broader processes of inclusion and exclusion. Whereas exclusion is a relatively straightforward concept, inclusion is more ambivalent. It can imply active participation, but at the same time it can imply passive integration, absorption, or even exploitation.

These processes are investigated in light of recent regulatory changes at the global level, such as Basel II or the governance of derivatives markets, with special emphasis on how these changes are implemented in the European Union. In particular, the contributions in this volume shed light on issues arising from the application of features from an AngloSaxon context (self-regulation, financial literacy, privatization of pensions, etc.) in the entirely different institutional setting of continental Europe and the conflicts involved.

The authors ask whether the inclusive mechanisms and processes of regulatory change observed are, as often portrayed, substantial enough to offset exclusionary tendencies (Porter 2001 and in this volume), and whether the recently evolving mechanisms of multi-level governance, which entail multiple levels of public-sector and private authority, offer 
an alternative to national public authority in terms of democratic legitimacy.

In the following paragraph, the demands on democratic legitimacy in financial governance are first discussed, in particular in areas where formal authorization is not available or of disputed value - as in the international sphere. Based on these normative legitimacy criteria, the procedural and substantive prerequisites of inclusion in financial governance arrangements that effectively increase societal participation are then reviewed and contrasted with phenomena of inclusion and exclusion in practice. Before this discussion, the few available studies on the distributive effects of finance are summarized. These studies are rare because financial matters undoubtedly have a sizable impact on everyday life, but the channels through which these mechanisms are exercised are often meandering, difficult to grasp and beyond the awareness of the general public. Knowing these effects is decisive, as financial governance is exclusively associated with efficiency most of the time and with pursuing the sole objective of preserving financing stability. The latter is in fact a common global concern, as crisis contagion exerts negative spillover effects throughout the world and the macroeconomic costs are high, sometimes even severe and long-lasting. Moreover, the subject matter requires sophisticated technical expertise which is not easily accessible to the general public. Both features add to the popular understanding that standards of financial regulation are preferably set by expert institutions, with accountability being exercised vis-à-vis the overall financial sector at best.

\section{Financial Structure and Distribution of Income and Wealth}

Impact studies on financial governance typically examine how financial services are affected, or they look at its consequences for efficiency in terms of financial stability, growth or macroeconomic volatility (e.g. Goodhart 2005, OeNB 2003). But different regulatory regimes have distinct distributive effects which go far beyond the narrow scope of the financial sector itself. Most of the case studies presented in this volume describe regulatory reform initiatives that set off a transformation of European financial systems toward arm's length financing, for instance through the promotion of private pensions and the emergence of a European market for corporate control. In the following an overview is given of the channels through which the changes in the financial structure have an impact on income and wealth distribution.

One might think of at least four different channels by which financial structure can impact the distribution of income and wealth (Mooslechner 2003). First, a direct and most dominant channel is the way in which corporate governance modes have an impact on resource allocation 
among shareholders and other stakeholders. Financial structures leading to the adoption of a focus on shareholder value creation in firms restrict the ability to transfer resources from profitable sectors to less profitable ones. In an established market for corporate control, the increased attention to short-term profitability in an attempt to increase return on equity will distribute income from other stakeholders to shareholders (de Jong 1997). While supporters of an active market for corporate control claim that takeovers will direct corporate assets toward more efficient uses, Shleifer and Summers (1988) argue that shareholders' gains result less from increased efficiency than from the ability of managers to breach the 'implicit contracts' of stakeholders (such as employees). As employment perspectives of employees with industry-specific skills are not adequately protected, they are vulnerable to a 'breach of trust' which aims to distribute wealth to shareholders at the expense of the firm's long-term performance. This 'breach of trust' hypothesis is also supported by Deakin et al. (2002).

A second and closely related channel through which financial structure impacts income and wealth distribution can be derived from the idea of institutional complementarities, according to which different models of market economies are constituted by a broad set of complementary and mutually reinforcing institutions such as industrial relations, innovation and training systems, as well as financial structure (Hall and Soskice 2001). A change in one institutional pattern will set changes in motion in other subsystems (for a critique, see Streeck 2003 or Schuberth and Schürz 2004). Convergence toward a market-based financial system should thus alter industrial relations and the way in which conflicts of interest between social partners are orchestrated. Centralized and coordinated wage bargaining enables more equal outcomes from a macroeconomic perspective. In general, the bargaining power of trade unions, consumers and pensioners will probably decline vis-à-vis financial investors (see Schmitz in this volume, who investigates this phenomenon in the case of private pensions). Furthermore, given the dispersion of corporate control across countries, territorially based bargains become less effective (Underhill 2002). Though causality is difficult to establish and the determinants of income distribution are manifold, it can be observed that bank-based economies generally demonstrate more equal income distribution than market-based systems. The most recently available Gini coefficients for countries classified as more bank-based vary from 0.25 to 0.27 , while those categorized as market-based had a much higher Gini coefficient, ranging from 0.31 in 
Australia to 0.37 in the United States. ${ }^{2}$

Third, the secondary distribution of income is affected inasmuch as the emphasis on shareholder value creation has an impact on how risk sharing is organized in society. Typically, households in a financial system dominated by market-based financing bear a greater share of risk than in bank-based systems, where intermediaries absorb and pool risks for households (Allen and Gale 2001). Fourth, and closely related to the last two points, is the role of the hegemony of ideas in creating support for shareholder value orientation and exerting a negative impact on distribution. The latter is the most indirect - but nevertheless equally important - transmission channel. Market-based instruments for retirement savings or health care provision are not only promoted through pecuniary incentives via fiscal measures and/or the propagation of higher expected yields among risk-averse households. They are also advertised by means of a hegemonic discourse that generates an attitude of selfresponsibility, self-interest and self-determination (Schürz in this volume), norms that institute the moral superiority of the distributive outcomes of the market over those of the redistributive welfare state (Bourdieu 1998). Thus, financial governance is exercised through formal as well as informal channels, via values and the promotion of ideas. The transformation of the European financial system toward an Anglo-Saxon system might eradicate the prevailing welfare arrangements and make the principle of social solidarity less acceptable in society (Salacuse 2002). Therefore, as exemplified in the most recent regulatory reform initiatives at the European level, financial governance shapes the political, social and cultural sphere. Considering its impact on distribution, one would suspect that these initiatives need to be embedded in broad legitimation structures.

\section{Democratic Legitimacy}

One influential view in economic policy circles and supervisory authorities considers the financial governance of non-state actors to be exclusive expert terrain where satisfactory legitimacy is achieved if clear statutory objectives such as financial stability and transparency requirements are fulfilled. This kind of output legitimacy is considered sufficient if the goal of policy is to find a solution capable of improving the conditions of all individuals and groups in society. In contrast, a policy with redistributive consequences can only be legitimated by voters

\footnotetext{
${ }^{2}$ Bank-based: Finland, Germany, Sweden, Denmark and Austria. Arm's length (or market) based: Australia, Ireland, United Kingdom and the United States. See Luxembourg Income Study Key Figures (www.lisproject.org/key/figures/).
} 
or their elected representatives (Majone 1997). As the perception of the existence of distributive effects in financial regulatory reform is minimal or even non-existent, this influential view considers output legitimacy to be a sufficient prerequisite for democratic legitimacy. However, any policy with redistributive impact requires input legitimacy, that is, the incorporation of social groups in financial governance.

While the focus on input legitimacy is important, it also has its problems and limitations. In order to avoid the inherent limits of restricting the analysis to either input or output legitimacy, the contributions to this volume simultaneously look at inclusion and exclusion from a narrow (procedural) and a broader (substantive) perspective. The narrow perspective examines major elements of input legitimacy: Who is part of the decision-making bodies, whose voice is heard, who is excluded, who is finally assigned which tasks, and what are the mechanisms by which inclusion and exclusion take place? From a substantive perspective, these procedural aspects are linked with the economic, social, political and cultural effects of the specific regulatory measures taken. This is crucial as the interests of actors are sometimes vague or opaque and often subject to change.

A conceptualization of financial governance based solely on procedure lacks decisive linkages between developments in the political (in the areas of policy, polity and politics), economic and social spheres. From a procedural perspective only, accountability and legitimacy are expected to increase with the number of actors involved in multi-level decisionmaking, for instance by including non-governmental organizations in the process or by increasing transparency (Wolf 2002). However, if the decisions taken have negative distributive effects on those who never have a chance of inclusion, or if the decisions promote a discourse of anti-solidarian values which help to reconstruct the perception of interests and thus feed back into politics, the picture changes (Schürz in this volume). Equally subject to further consideration is the view that in light of recent re-regulatory efforts a retreat of the state is not observable. Hence public national interests should be well represented and democratic legitimacy secured if deliberation on regulatory reform is restricted to the national technocratic elite. National experts and representatives of national authorities are incorporated in formal and informal international, multi-level expert networks. These constitute epistemic communities that share a similar cognitive and normative orientation toward key objectives. Expert networks are often seen as a quasi-experimental device able to promote deliberative problem-solving within society (Bohmann 2004). However, by these mechanisms, national representatives have probably become more distant from the instruments that have traditionally ensured democratic accountability at the domestic level. 
Even more contested is the legitimacy of private, supranational and independent agencies, which is beyond the reach of public opinion, parliaments and electorates. Ironically, the decision to delegate policies to independent institutions, agencies and private associations is often taken specifically in order to increase legitimacy. In fact, the recent changes in global financial regulation are often portrayed as an inclusive process: Governance is now less exercised by imposing a centralized set of administrative procedures from an organized hierarchy, a powerful political authority, but rather by a decentralized, sometimes selfregulatory system of codes, rules and standards developed through deliberation and consultation in a variety of dispersed and often informal institutions and networks (for a discussion, see Porter 2001 and in this volume). Strengthening the role of non-state actors in decentralized public-private policy networks is supposed to improve the input legitimacy of governance (Wolf 2002). But a mere focus on procedural aspects without taking account of the substantive features regarding the precise social and economic impact of reforms taken may send misleading signals concerning the legitimatory quality of the process.

\section{The Dynamics of Inclusion and Exclusion in Recent Financial Regulatory Reform}

The contributions in this volume explore the consequences of these considerations in a series of detailed case studies on the most recent developments in financial governance reform. From these studies, several common themes and patterns emerge.

In financial services research, the term 'financial exclusion' has taken hold to designate the lack of access of certain groups of society to basic infrastructure in the financial field. But - as the authors of this volume demonstrate - financial governance arrangements can also produce far broader effects through their impact on the real economy and on public discourse concerning issues of political economy. Far from being a technical affair optimized for the benefit of all, different financial governance arrangements have different distributional effects. From the perspective of democratic legitimacy, decision-making on policies with distributional effects should involve the broad-based participation of those affected by it wherever possible.

As has been shown by a growing body of literature and as underlined in the contributions to this volume, however, the setting and administration of financial governance arrangements are characterized by narrow participation mainly consisting of experts from national administrations, independent regulatory agencies and industry representatives. While reform in financial governance arrangements has been a widespread and ongoing phenomenon in recent years, its 
sometimes large distributional consequences have not been accompanied by a broadening of the interests represented in their definition.

The emerging picture is rather clear: Power in the political sphere shapes economic outcomes, and economic power translates into political power. Political exclusion and economic exclusion are correlated. This is underlined by the analyses undertaken by Lütz, Redak, Schmitz, Tsingou, Underhill and Weber in this book. On this account, a lack of inclusion seems to be the main problem from the viewpoint of democratic legitimacy, but things are not that simple.

Criticism regarding a lack of representation can endanger the legitimacy of governance processes and market expansion projects. Therefore, one recurring strategy in international financial governance arrangements is to selectively include some of the voices of those formerly excluded from the governance polity. A recent example of this in the domain of international financial governance is the foundation of the G20, which Porter (2001) describes as a reaction of the leading industrial countries to criticism about the exclusionary character of G7led financial governance. In a case study on Basel II, Vanessa Redak shows that the elaboration of the framework was based on far broader participation and more open consultation than its predecessor, Basel I. Similarly, Beat Weber emphasizes the consultation and transparency provisions attached to the regulatory reform process in the Lamfalussy procedure used in implementing the European Union's Financial Services Action Plan. But these steps toward greater formal transparency and the broadening of membership by public consultation procedures have not resulted in increased visibility or weight for views which oppose the approaches favored by industry and regulatory expert circles up to now. This can be interpreted as an example of the ambivalent nature of inclusion. Because the process is ambivalent, the inclusion of new actors in the decision-making process does not automatically result in policy changes. In addition to factors such as limited voting power, a lack of resources and other asymmetries limit the influence of new ideas. Hegemonic ideas can survive, leaving policies unchanged and turning the inclusion of new actors into a mere legitimacy-enhancing measure. Being included in formerly exclusive governance bodies also makes these groups (jointly) responsible, e.g. for promoting existing governance arrangements which continue to produce economic exclusion. Aspects of this can be identified, for example, in processes to ensure the 'democratic accountability' of the EU's financial services legislation process, as Weber shows in his case study.

While this points to the possible coincidence of formal political inclusion and economic exclusion, the opposite is also observable: Political exclusion can go hand in hand with economic inclusion. 
Governance arrangements exclusively dominated by industry and administrations can be instrumental in economic inclusion strategies. For instance, governance reform may be essential to enabling the inclusion of new groups when it comes to opening up new markets through regulatory reform. Schmitz's examination of efforts to promote private pension schemes by devising regulations which included guarantees for customers (which were withdrawn as soon as they became applicable) traces the pitfalls included in this process for beneficiaries in the case of private pensions. Another example is the handling of the problem of 'financial exclusion', as explored by Martin Schürz in his case study: Experience in the United States and United Kingdom has shown that a well-developed financial market can go hand in hand with widespread financial exclusion - for example leaving fewer people with access to the financial system. Debates about this problem have led to reform efforts which aim to transform the groups concerned into financial services consumers. Educational efforts are envisaged to increase the ability of the excluded to become included, but research highlights that at least some of those excluded do not regard access to the official financial system as their main problem. More importantly, exclusion seems to result from both a lack of resources among the excluded and from certain deficiencies on the supply side of the financial sector (see Schürz in this volume). Their exclusion as customers in the financial sector seems to be related to exclusion in other areas of society, among them governance processes regarding control over the distribution of resources and the regulation of the financial system.

Currently, exclusion from decision-making sometimes does not give rise to widespread complaints. This is because finance is considered the exclusive terrain of experts, pointing to widespread exclusion through expertise. In financial governance matters, asymmetries in expertise are common, as expert knowledge represents a normative framework. After events of crisis and change, this attitude is sometimes subject to revision. For instance, greater public awareness of the costs of financial crises borne by taxpayers may give rise to demands for the greater inclusion of public concerns and representatives in rule-making for crisis prevention and negotiations about burden-sharing.

These aspects of the dynamics of inclusion and exclusion highlight the risks of using these terms as elegant disguises for 'good' and 'bad'. One important lesson to be drawn from the contributions in this book is that when assessing governance processes, one has to look at the various dimensions of inclusion and exclusion simultaneously. 


\section{STRUCTURE OF THIS VOLUME}

The volume is divided into two parts. Part I discusses conceptual and theoretical issues of financial governance in an attempt to conceptualize governance as an outcome of conflicting interests which repeatedly produce inclusion and exclusion. Part II presents case studies on the most recent issue areas.

In the first contribution, Geoffrey Underhill surveys the most important approaches of governance theory from mainstream economics and political economy. He criticizes the predominant tendency to see the market and state as dichotomous. Markets are politicized entities, and political actors have economic motives. In order to capture these aspects more effectively, Underhill calls for a view of political authority and markets as analytical parts of an integrated ensemble of governance, the state-market condominium. Within this condominium, significant changes have occurred in recent times. Above all, the state has become more a facilitator of economic internationalization than a protector of broad domestic interests. Drawing conclusions for the International Financial Architecture, Underhill calls for a redesign in order to facilitate access to the policy process for interests which are currently excluded, arguing that there must be a greater role for democracy in governing international finance. Indeed, enhancing political legitimacy is both necessary and possible: While economic theories of governance deny this, the state-market condominium model sees room for a variety of governance mechanisms which are compatible with market processes.

Susanne Lütz takes a closer look at the dynamics within and triggered by this condominium. According to Lütz, preferences and power relationships between states and market actors are key variables. In recent times, they have increasingly joined forces and sometimes forged modernization coalitions in order to promote domestic financial reform. These coalitions are heavily influenced by the changing international landscape.

The dynamics of 'uploading' and 'downloading' as well as imitation and learning take place within an environment of international regulatory competition. Institutional legacies and the contingencies of politics yield the result that there is no common international pattern concerning the details of regulatory models. Globalization in financial regulation is a selective process which exhibits features of multi-level governance.

Part II presents case studies on the most recent issue areas, addressing the topics of financial market integration in the European Union under the Lamfalussy process, Basel II, the regulation and promotion of pension funds, the international derivatives market and the proliferation of financial literacy programs. Special emphasis is placed on the issue of how inclusion and exclusion are organized in the process of setting up 
regulation. With its focus on political financial sector reform in the European Union, this section sheds light on issues arising from features of the Anglo-Saxon model (liberalization, financial literacy, privatization of pensions, etc.) in the entirely different institutional setting of continental Europe.

In asking "Who Governs?" Brigitte Unger critically evaluates the financial governance debate. In her view, power relations are not addressed in an adequate way. In an effort to bring power back into the debate on financial governance she elucidates seven approaches that might be useful for exploring who governs financial markets, among them the concept of hegemony and epistemic community governance.

Tony Porter provides an empirical assessment of the claims surrounding global finance: Critical views highlight the exclusionary aspects of finance and sometimes portray it as a unified actor which is able to force its will upon people globally. The supportive view tends to portray the globalization of finance as a process which brings benefits to all by promoting openness and competition. One way to assess this debate is to look at the ways in which private-sector actors are organized in global finance. Porter's preliminary finding is that there is an impressive amount of organizing going on in finance, but the organizational structure shows features of regional and sectoral dispersal. While it would certainly be premature to draw firm conclusions about the political influence of finance from these studies, it does open an avenue for empirical research.

The EU has seen a wave of financial integration efforts since the turn of the millennium. In applying insights derived from the analytical frameworks elaborated by Geoffrey Underhill and Susanne Lütz, Beat Weber contextualizes these developments in political and economic changes on the global and European scale. Looking at the dimensions of policy, politics and polity of financial governance in the EU, Weber presents significant evidence of exclusion. While the legislative initiatives taken by the EU have effects which transcend the financial sector, the policy process and the polity responsible for decision-making is dominated by the interests of financial market firms.

In the US, the problem of financial exclusion has been a recurring topic in policy debates on the financial sector for quite some time. Martin Schürz investigates the recent wave of efforts to increase the financial literacy of the US public. Financial education initiatives are officially labeled as a tool to tackle the financial exclusion of the poor, but the sparse empirical evidence available does not indicate that such initiatives can make a meaningful contribution toward this goal. A lack of education and knowledge is not a major cause of the problem, nor do literacy efforts seem to make much difference to the outcomes. The fact that financial literacy initiatives are increasingly put forward can be 
interpreted as an attempt to legitimize economic exclusion by blaming the lack of knowledge among those excluded. By appealing to hegemonic values, above all individual responsibility, decisive distributional issues are cast in the shadows.

Over-the-counter (OTC) derivatives have gained prominence in the past 15 years. Eleni Tsingou traces the extent to which the governance of OTC markets has become a policy issue and explains that two elements have prevailed in policy debates: (i) OTC derivatives are just another type of financial instrument and do not require special treatment, and (ii) best practice (as defined by the private sector) and private mechanisms of monitoring are both sufficient and effective. The governance of OTC markets essentially takes the form of monitored self-regulation and selfsupervision. Yet derivatives arguably merit greater attention because they carry leverage and are increasingly used not just to hedge against risk, but also to embrace risk. In this context, the paper argues that the governance arrangements of OTC markets show the way in which the functions of regulation and supervision are changing: Governance is shared among a transnational policy community of public and private-sector parties, and private interests are internalized in financial policy processes.

In an analysis of Basel II, one of the best-known recent regulatory reforms in financial governance, Vanessa Redak focuses on the relationships between public and private agents. In this respect, Basel II gives a mixed picture. Whereas private agents - like rating agencies expect an increase in their authority, the discretion of public supervisory authorities will also increase, at least in some respects. Furthermore, Basel II is an example in which private industry representatives have become more important, as their concerns have been internalized in the new regulatory framework. In contrast, the influence of labor and consumer groups is largely absent in the Basel II process, despite the fact that the reform will have a significant impact on the economy as a whole.

One of the most prominent changes in financial markets in recent years has been the growing importance of private pension funds in the provision of social security. After a few years of disappointing yields as well as episodes of mismanagement and fraud, the high hopes held toward these vehicles in the 1990s have given way to a more critical view of pension funds. Particular attention is increasingly turning toward their governance structures and the question of how much this industry operates in the interest of its alleged beneficiaries. Stefan W. Schmitz examines these issues in a case study on Austria, a country in which private pension schemes have been given a boost by the government only recently, therefore making the country a likely candidate for featuring 'state-of-the-art' governance provisions. In an analysis of recent developments in the sector, Schmitz concludes that incentive structures to protect beneficiaries' interests against the shareholders in Austrian 
pension funds are rather weak and expose them to considerable economic and political risks. It remains unclear whether it is at all possible to eliminate this problem, thus highlighting the limitations of privatizing old-age provision.

\section{CONCLUSION}

Financial governance can be interpreted as a 'state-market condominium' consisting of experts delegated by industry, national administrations and independent regulatory agencies. The precise effects of this situation on inclusion and exclusion have rarely been explored. Financial markets are gaining unprecedented importance, extending their reach and thereby affecting more areas of life than ever before. These changes - both in the reach of the financial sector and in the polity responsible for its governance - suggest that the question of who is in and who is out is a central theme in understanding current processes in this area. The concept of inclusion and exclusion is intended to cope with the interconnected processes of change occurring in the economic and the political sphere of financial governance.

Obviously, the linkages between exclusion in the political and economic spheres are important. However, one has to be very careful about simply reacting to them with a call for more inclusion. Inclusion is a double-edged sword which can have either a substantial or a merely symbolic meaning. When democratic legitimacy is reduced to a vague notion of inclusion, it can be employed to legitimate situations with important exclusionary aspects. For this reason, inclusion and exclusion should be viewed not only from a procedural but also from a substantive perspective. The latter enriches a purely procedural analysis with an investigation of the economic, social, political and cultural effects of the specific regulatory measures taken.

While the current trend toward a more market-oriented framework in financial governance is often justified to include new groups in previously unexplored market niches, this inclusion does not provide for any participation of the targeted groups apart from their role as (passive) consumers. Substantial inclusion would require the ability to take part in framing the workings of market processes, thus participating in the decision as to how and under what terms one would like to be included. The fact that participatory inclusion rarely exists under current governance arrangements points to significant exclusion in this area and a definite need to develop modes of inclusion in order to make it more widespread and substantial. 


\section{REFERENCES}

Allen, Franklin and Douglas Gale (2001), 'Comparative Financial Systems: A survey', Wharton School Center for Financial Institutions Working Paper 0115.

Bohmann, James (2004), 'Deliberative Democracy as an Institutional Mode of Inquiry: Pragmatism, Social Facts and Normative Theory', in Peter Mooslechner, Helene Schuberth and Martin Schürz (eds), Economic policy under uncertainty. The role of truth and accountability in policy advice, Cheltenham, UK and Northampton, MA, USA: Edward Elgar, pp. 40-62.

Bourdieu, Pierre (1998), The Essence Of Neoliberalism, Le Monde, December, available at http://www.analitica.com/biblioteca/bourdieu/neoliberalism.asp

Cerny, Philip G. (2005), 'Power, markets and accountability: the development of multi-level governance in international finance', in Andrew Baker, David Hudson and Richard Woodward (eds), Governing Financial Globalization. International political economy and multi-level governance, London: Routledge, pp. 24-48.

De Jong, Henk W. (1997), 'The governance structure and performance of large European corporations', Journal of Management and Governance, 1 (1), 527.

Deakin, Simon, Richard Hobbs, David Nash and Giles Singer (2002), 'Implicit Contracts, Takeovers, and Corporate Governance: In the Shadow of the City Code', ESRC Centre for Business Research Working Paper 254, Cambridge, UK: ESRC Centre for Economic Research.

Dingwerth, Klaus (2004), 'Democratic Governance beyond the State', Global Governance Working Paper No 14, December.

Goodhart, Charles A.E. (2005), 'Financial Regulation, Credit Risk and Financial Stability', National Institute Economic Review, 192 (1), 118-27.

Grabel, Ilene (2003), 'Ideology, Power and the Rise of Independent Monetary Institutions in Emerging Economies', in Jonathan Kirshner (ed.), Monetary Orders: Ambiguous Economics, Ubiquitous Politics, Ithaca: Cornell University Press, pp. 25-52.

Hall, Peter A. and David W. Soskice (eds) (2001), Varieties of Capitalism. The Institutional Foundations of Comparative Advantage, Oxford: Oxford University Press.

Kirshner, Jonathan (2003), 'Money is politics', Review of International Political Economy, 14 (4), 645-60.

Kjaer, Anne Mette (2004), Governance, Cambridge: Polity Press.

Macey, Jonathan (1998), 'Regulation and Disaster: Some Observations in the Context of Systemic Risk', in Robert E. Litan and Anthony M. Santomero (eds), Brookings-Wharton Papers on Financial Services, Brookings Institution Press, pp. 405-25.

Majone, Giandomenico (1997), 'Independent Agencies and the Delegation Problem: Theoretical and Normative Dimensions', in Bernard Steunenberg and Frans van Vught (eds), Political Institutions and Public Policy. Perspectives on European Decision Making, Dordrecht: Kluwer Academic Publishers, pp. 139-56. 
Mooslechner, Peter (2003), 'The Transformation of the European Financial System - A Brief Introduction to Issues and Literature', OeNB Workshop Series No 1.

OeNB (2003), 'Finance for Growth', Focus on Austria, 1/2003.

Porter, Tony (2001), 'The Democratic Deficit in the Institutional Arrangements for Regulating Global Finance', Global Governance, 7, 427-39.

Salacuse, Jeswald W. (2002), 'European Corporations American Style? Governance, Culture and Convergence', paper presented at a conference hosted by the John F. Kennedy School of Government, April 11-12.

Schuberth, Helene and Martin Schürz (2004), 'Paradoxes of Financial Governance in U.S. Capitalism', in I.D. Salavrakos (ed.), Aspects of Globalisation, Regionalisation and Business, London: London Metropolitan University, pp. 141-57.

Shleifer, Andrei and Lawrence Summers (1988), 'Breach the trust in hostile takeovers', in Auerbach (ed.) 'Corporate Take-overs: Causes and Consequences', University of Chicago Press: London and Chicago, 33-68.

Streeck, Wolfgang (2003), 'Taking Uncertainty Seriously: Complementarity as a Moving Target', OeNB Workshop Series No 1.

Underhill, Geoffrey (2002), 'Global Integration, EMU, and Monetary Governance in the EU: the political economy of the "stability culture", in Kenneth Dyson (ed.), European States and the Euro, Oxford: Oxford University Press, pp. 31-52.

Wolf, Klaus Dieter (2002), 'Contextualizing Normative Standards for Legitimate Governance beyond the State', in Jürgen R. Grote and Bernard Gbikpi (eds), Participatory Governance, Opladen: Leske und Budrich, pp. 35-50. 